\title{
A INVISIBILIDADE DAS DOENÇAS E ACIDENTES \\ DO TRABALHO NA SOCIEDADE ATUAL
}

\author{
THE INVISIBILITY OF DISEASES AND INJURIES \\ OF WORK IN CURRENT SOCIETY
}

Márcia Cunha Teixeira*

\section{RESUMO}

O objetivo deste artigo é demonstrar que a saúde dos trabalhadores não tem merecido de fato visibilidade e a atenção da sociedade em geral, incluindo o Estado. A leitura de textos sobre a proteção jurídica à saúde do trabalhador, bem como de publicações de engenharia de segurança, de medicina do trabalho, de sociologia do trabalho e de psicologia social e do trabalho possibilitou o estudo da matéria, de natureza multidisciplinar, e de sua evolução, desde a Revolução Industrial até a criação da Organização Internacional do Trabalho (OIT), passando pelas etapas da medicina do trabalho, da saúde ocupacional, da saúde do trabalhador, até a vertente da qualidade de vida do trabalhador. A proteção jurídica à saúde do trabalhador é analisada por meio das normas em vigor, nos âmbitos internacional e nacional. As transformações ocorridas no mundo, com a globalização, a evolução tecnológica e as mutações que vêm ocorrendo desde a virada do século XX para o século XXI, com metamorfoses no processo de produção do capital e repercussões no processo de trabalho, são enfocadas, para ressaltar que outras formas de adoecimento passaram a ter visibilidade entre os trabalhadores, como as Lesões por Esforços Repetitivos/Distúrbios Osteomusculares Relacionados ao Trabalho (LER/DORT) e os transtornos psíquicos. Por fim, este estudo examina, diante do atual crescimento econômico brasileiro, com milhões saindo de baixo da linha da pobreza, elevação de consumo e aumento da classe média, conjuntura que permite o desenvolvimento de obras, inclusive financiadas pelo poder público, se os agravos à saúde dos trabalhadores são visíveis e se o respeito às normas protetoras é praticado e incentivado por todos.

(*) Doutoranda em Direito, Universidade de São Paulo (USP); Mestre em Direito, USP. Advogada trabalhista; Assessora, Tribunal Regional do Trabalho da $2^{a}$ Região (SP). São Paulo/SP - Brasil. E-mail: $<$ mcteixeirasato@gmail.com>.

Texto recebido em 20.06.11. Revisado em 22.12.11. Nova revisão em 09.04.12. Aprovado em 12.04.12 


\section{Palavras-chave:}

Doença Ocupacional; Processo de Produção; Proteção Jurídica; Saúde do Trabalhador.

\section{ABSTRACT}

This article aims to show that workers health conditions have not actually been given visibility and also the attention of the society, including the Government. The contact with articles regarding the legal protection of workers' health, as well as safety engineering, occupational medicine, sociology of the work, and social and labor psychology led to the interdisciplinary approach of the subject and its historical development, since the Industrial Revolution until the foundation of the International Labour Organization (ILO), going through the occupational medicine and health phases and the workers' health, eventually approaching the worker's life quality. The worker's health legal protection is seen through the Brazilian and International rules applicable. The changes that occurred as a result of globalization, technology and mutations started at the end of the 20th century and beginning of the 21st, and affected the industrial manufacturing process, which turned to the acknowledgement of new ailments among the workers, such as Repetition Strain Injuries/WorkRelated Musculoskeletal Disorders (RSI/ WRMD) and the mental disorders. Hence, this article examines whether the decrease on workers' health quality is visible and the compliance to the protective rules is enforced and encouraged, against the Brazilian economic growth that takes millions out of the poverty threshold and enables the execution of projects, even projects supported by the Brazilian Government.

\section{Keywords:}

Industrial Manufacturing Process; Legal Protection; Occupational IIIness; Worker's Health Conditions.

\section{INTRODUÇÃO}

As últimas décadas foram de rápidas e significativas transformações no mundo; vivemos a globalização e a evolução tecnológica, com metamorfoses no processo de produção do capital e repercussões no processo de trabalho.

Concomitantemente às enfermidades clássicas decorrentes do processo de trabalho, manifestações mais complexas de adoecimento passaram a ter visibilidade entre os trabalhadores, como as Lesões por Esforços Repetitivos/ 
Distúrbios Osteomusculares Relacionados ao Trabalho (LER/DORT), que passaram a ter visibilidade social no Brasil na década de 1990, já no final do século XX.

Transtornos mentais, como estresse, depressão (esta, de maior incidência) e outras moléstias, ocupam a terceira posição entre as causas de concessão de benefícios previdenciários, acidentários ou não acidentários.

Em 2009 foram registrados 723,5 mil acidentes de trabalho no Brasil, dos quais aproximadamente 2,5 mil terminaram em mortes, uma média de quase sete mortes por dia. Índices alarmantes como esses servem-nos de alerta de que não basta o reconhecimento do direito à saúde do trabalhador, para que ele seja efetivamente respeitado. Por isso, tecemos reflexões e buscamos alternativas, para que todos possam desfrutar de um ambiente de trabalho saudável e digno.

\section{SAÚDE DO TRABALHADOR: RECONHECIMENTO DO DIREITO}

\section{Da Revolução Industrial à criação da OIT}

Antes do advento da Revolução Industrial a produção era manual e, no processo de desenvolvimento do capitalismo, duas etapas são bem definidas: 0 artesanato, forma de produção característica da Baixa Idade Média, de caráter familiar, na qual o produtor, o artesão, possuía os meios e realizava todas as etapas da produção, ou seja, não havia divisão do trabalho ou especialização; nesse período a produção artesanal estava sob controle das corporações de ofício. A manufatura predominou ao longo da Idade Moderna; aqui já ocorre um aumento na produtividade do trabalho, devido à divisão social da produção, em que cada trabalhador realizava uma etapa na confecção de um produto. Registra-se, aqui, a interferência do capitalista no processo produtivo, passando a comprar a matéria-prima e a determinar o ritmo de produção.

A partir da máquina, fala-se numa primeira, numa segunda e até numa terceira e quarta Revolução Industrial. Assim, o processo de industrialização é uma etapa do processo produtivo, que teve um primeiro momento, o da energia a vapor no século XVIII; um segundo momento, o da energia elétrica no século $\mathrm{XIX}$; e, embora suscite questionamentos, podemos falar num terceiro e quarto momentos, representados respectivamente pela energia nuclear e pelo avanço da informática, da robótica e do setor de comunicações ao longo dos séculos XX e XXI.

Desde o início da industrialização, no século XIX na Europa, dá-se a produção em escala, possibilitada pela máquina, que favorece a formação definitiva do capitalismo. Os detentores do capital, donos dos meios de produção, passam a se utilizar das máquinas e da força de trabalho de outros homens. Walter Benjamin, citando Karl Marx, diz que o homem que não possui outra propriedade que a sua força de trabalho está condenado a ser "escravo de outros homens, 
que se tornaram... proprietários". (1) Trata-se, assim, da exploração de força de trabalho de alguns homens por outros homens, entre os quais a diferença básica é a propriedade.

A Revolução Industrial traz o incremento da produção em série, que forja a competição do homem com a máquina. Leo Huberman observa que as máquinas, ao invés de tornarem mais leve o trabalho, o fizeram pior, pois eram eficientes e representavam tamanho capital para seus donos que não podiam parar; assim, tinham que trabalhar sempre. Os proprietários impunham jornadas de trabalho de 16 horas. Ressalta esse autor que "quando conquistaram o direito de trabalhar em dois turnos de 12 horas, os trabalhadores consideraram tal modificação como uma bênção". (2)

Intensificaram-se a exploração e o consumo da força de trabalho, submetida às condições laborais desumanas; ao mesmo tempo em que ocorre a expansão capitalista, aumenta a miséria, cresce o número de doentes, mutilados e mortos nos ambientes de trabalho.

Com a chegada das máquinas e do sistema fabril, a linha divisória entre ricos e pobres tornou-se mais acentuada, como destaca Leo Huberman. Esse autor ressalta a situação dos artesãos, que antes ganhavam o suficiente para viver, e agora, devido à competição entre o processo artesanal e as mercadorias produzidas pela máquina, viram-se na miséria. ${ }^{(3)}$

Sebastião Geraldo de Oliveira descreve bem as condições de trabalho da época e a ausência de preocupação patronal quanto à saúde dos trabalhadores:

(...) Contando com a sorte e o instinto de sobrevivência, cabia ao próprio trabalhador zelar pela sua defesa diante do ambiente de trabalho agressivo e perigoso, porque as engrenagens aceleradas e expostas das engenhocas de então estavam acima da saúde ou da vida "desprezível" do operário. Segundo as concepções da época (o laissez-faire), os acidentes, as lesões e as enfermidades eram subprodutos inevitáveis da atividade empresarial e a prevenção era incumbência do próprio trabalhador. (...)(4)

A utilização da máquina a vapor disseminou-se na Inglaterra, e por volta de 1800 estava em uso nas minas de carvão e de cobre, fundições, cervejarias e usinas de algodão.

A busca frenética por mão de obra impulsionou o comércio de crianças, vendidas por pais miseráveis aos intermediários, que as revendiam aos empregadores. Leo Huberman descreve como se dava a utilização do trabalho infantil:

(1) BENJAMIN, Walter. Sobre o conceito de história. In; BENJAMIN, Walter. Obras escolhidas.

São Paulo: Brasiliense, 2008, p. 227.

(2) HUBERMAN, Leo. História da riqueza do homem. Rio de Janeiro: Guanabara, p. 177.

(3) op. cit.

(4) OLIVEIRA, Sebastião Geraldo de. Proteção jurídica à saúde do trabalhador. São Paulo: LTr, 2010, p.49. 
(...) O trabalhador infantil não era novidade. (...) Mas antes o trabalho das crianças era complemento do trabalho dos pais; agora, passava a ser a base do novo sistema. Antes, as crianças trabalhavam em casa, sob a direção dos pais, com horários e condições por estes determinados; agora, trabalhavam em fábricas, sob a direção de um supervisor cujo emprego dependia da produção que pudesse arrancar de seus pequenos corpos, com horários e condições estabelecidas pelo dono da fábrica, ansioso de lucros. Até mesmo um senhor de escravos das Índias Ocidentais poderia surpreender-se com o longo dia de trabalho das crianças. (... $)^{(5)}$

A primeira intervenção estatal para minorar esse quadro tão dramático veio com a aprovação, em 1802, pelo Parlamento britânico, da "primeira lei de proteção aos trabalhadores: a Lei de Saúde e Moral dos Aprendizes, que estabelecia o limite de 12 horas de trabalho por dia, proibia o trabalho noturno, obrigava os empregadores a lavar as paredes das fábricas duas vezes por ano, e tornava obrigatória a ventilação destas". ${ }^{(6)}$

Diogo Pupo Nogueira considera que a primeira legislação eficiente no campo da proteção ao trabalhador foi o Factory Act, baixado na Inglaterra em 1833, pois

aplicava-se a todas as empresas têxteis onde se usasse força hidráulica ou a vapor; proibia o trabalho noturno aos menores de 18 anos e restringia as horas de trabalho destes a 12 por dia e 69 por semana; as fábricas precisavam ter escolas, que deveriam ser frequentadas por todos os trabalhadores menores de 13 anos; a idade mínima para o trabalho era de nove anos, e um médico devia atestar que o desenvolvimento físico da criança correspondia à sua idade cronológica. ${ }^{(7)}$

As primeiras leis de acidentes do trabalho surgiram na Alemanha, em 1884 , e nos anos seguintes legislação a respeito da matéria passou a vigorar em vários países da Europa.

No Brasil a questão foi disciplinada pela primeira vez por meio do Decreto Legislativo $\mathrm{n}^{\circ} 3.724^{(8)}$, de 15 de janeiro de 1919. Assim, com o passar do tempo os serviços de medicina do trabalho começam a ser implantados nas empresas, sob sua responsabilidade; em alguns países há a criação de Inspetoria do Trabalho, pertencente ao poder público, para fiscalizar as condições de trabalho nas fábricas.

Manifestações de trabalhadores e reivindicações apresentadas em congressos realizados durante a Primeira Guerra Mundial levaram a Conferência

(5) HUBERMAN, Leo. op. cit., p. 180.

(6) NOGUEIRA, Diogo Pupo. Introdução à segurança, higiene e medicina do trabalho. In:Curso de medicina do trabalho. São Paulo : Fundacentro, 1979, v. 1, p. 6.

(7) Id. Ibid.

(8) BRASIL. Decreto $n^{\circ} 3.724$, de 15 de janeiro de 1919, Regula as obrigações resultantes dos accidentes no trabalho (sic). Disponível em: <http://www.acidentedotrabalho.adv.br/leis/DEC-003724/ Integral.htm>. Acesso em: 2 jul. 2012. 
da Paz de 1919 a aprovar o Tratado de Versailles, que na sua Parte XIII dispôs sobre a criação da Organização Internacional do Trabalho (OIT).

Destaca Arnaldo Süssekind que esse tratado plurilateral, elaborado pelas nações vitoriosas na Primeira Guerra, afirmou no seu preâmbulo a vocação de estabelecer a paz universal, fundada sobre a base da justiça social; o tratado ressalta as condições de trabalho que "implicam para um grande número de pessoas em injustiça, miséria e privações”. ${ }^{(9)}$

Nessa esteira, o preâmbulo da constituição da OIT salienta:

(...) Considerando que existem condições de trabalho que implicam, para grande número de indivíduos, miséria e privações, e que o descontentamento que daí decorre põe em perigo a paz e a harmonia universais, e considerando que é urgente melhorar essas condições no que se refere, por exemplo, à regulamentação das horas de trabalho, à fixação de uma duração máxima do dia e da semana de trabalho, $(\ldots)^{(10)}$

Assim, esse preâmbulo continha tríplice justificação da ação legislativa internacional sobre as questões de trabalho: política (assegurar as bases para a paz universal); humanitária (existência de condições de trabalho que geram injustiça, miséria e privações) e econômica (melhoria das condições sociais). ${ }^{(11)}$

\section{Da Medicina do Trabalho à qualidade de vida do trabalhador}

Nesse contexto surge a Medicina do Trabalho, nascida ainda no século $\mathrm{XIX}$, que se configurou como a primeira forma clássica de enfrentamento do processo saúde/doença dos trabalhadores da produção capitalista.

No início do século XX, a criação da OIT, bem como o avanço do capitalismo, a necessidade de implementar a produção em série e aumentar a produtividade e a implantação de métodos como o Taylorismo e o Fordismo exigiam operários sadios; esses fatores contribuíram para o surgimento da Medicina do Trabalho.

No contexto da Segunda Guerra Mundial, verificou-se o avanço contínuo da tecnologia industrial, bem como o surgimento de novos processos mais avançados de produção, que provocaram, em decorrência, aumento de mortes, por acidentes e doenças do trabalho; além disso, vidas eram ceifadas na guerra e a intervenção da Medicina do Trabalho era insuficiente para a reprodução da força de trabalho.

O trabalhador era atendido somente depois de se acidentar no trabalho ou após a eclosão de doença ocupacional; o serviço médico não tinha autonomia para intervir no processo produtivo e eliminar as fontes das agressões.

(9) SÜSSEKIND, Arnaldo. Convenções da OIT. São Paulo: LTr, 1998, p. 17.

(10) op. cit. p. 53.

(11) op. cit., p. 17-18. 
Ensina Sebastião Geraldo de Oliveira que a consolidação da Medicina do Trabalho pode ser verificada pelas Recomendações da OIT $n^{\text {os }}$.97, de 1953, e 112, de 1959. Contudo, no Brasil, os serviços médicos eram espontaneamente adotados pelas grandes empresas, pois somente passaram a ser obrigatórios a partir de 1976, por força da Portaria do Ministério do Trabalho $n^{\circ} 3.237 / 72$, de acordo com o grau de risco e quantidade de empregados. ${ }^{(12)}$

Registre-se que a Medicina do Trabalho contribuiu para o aumento da produtividade, com seu caráter seletivo (aptidão para determinadas funções) e assistência dentro das empresas, com o objetivo de fazer o trabalhador retornar à atividade laboral o mais rápido possível. Portanto, era de interesse das empresas terem seu próprio serviço médico.

É preciso ressaltar que os horrores da Segunda Guerra Mundial fizeram despertar uma nova preocupação humanitária, com foco na paz social; encontram-se aí as raízes que propiciaram a evolução da concepção da Medicina do Trabalho.

Emerge então a concepção da Saúde Ocupacional ou Higiene Industrial, apontando a necessidade de se deslocar a ênfase no corpo do trabalhador para o ambiente de trabalho; saliente-se que essa mudança de abordagem é essencial. Ressalte-se, porém, que, para a prevenção de acidentes e doenças, a Saúde Ocupacional ou Higiene Industrial continuava a centrar-se no homem, por meio dos equipamentos de proteção individual. Desenvolve-se, assim, o modelo epidemiológico multicausal de doenças, ou seja, a doença é produzida por uma combinação de vários riscos, os denominados "fatores de risco", rompendo com o modelo monocausal da Medicina do Trabalho. Reconhece-se que, para estudar o ambiente de trabalho e os diversos fatores de risco de doenças no trabalho, é necessário contar com lógica multiprofissional.

Nesse sentido, destaca Sebastião Geraldo de Oliveira que se percebe, então, que era necessário intervir nas causas das doenças e dos acidentes do trabalho, modificando o ambiente de trabalho; para tanto não era mais possível contar somente com a atuação do médico, era preciso que outros profissionais especializados agissem, para prevenir os acidentes do trabalho:

(...) foi necessária a contribuição dos engenheiros, visando a reforçar a segurança nos processos produtivos; para evitar as doenças provocadas pelos agentes danosos, desenvolveu-se a higiene ocupacional. Iniciou-se, assim, o período do enfoque multidisciplinar na melhoria e do ambiente de trabalho, na fixação dos limites de tolerância para exposição aos agentes agressivos e na utilização dos equipamentos de proteção. ${ }^{(13)}$

De qualquer maneira, cumpre observar, em que pese ter emergido a concepção da saúde ocupacional, passando a enfocar a prevenção, com necessidade de atuação multidisciplinar, essa multiprofissionalidade se realiza ainda de forma

(12) OLIVEIRA. op. cit., p. 52-53.

(13) OLIVEIRA. op. cit., p. 54 
desarticulada. Nesse passo, o trabalhador permanece objeto, juntamente com o ambiente de trabalho, da intervenção dos profissionais visando à reprodução da força de trabalho e ao aumento da produção e acumulação do capital.

Ainda cabe salientar que o esforço de guerra, paradoxalmente, propiciou outra evolução, na área da medicina e segurança do trabalho. Na Segunda Grande Guerra, vários profissionais haviam se juntado aos estrategistas, para aperfeiçoar as armas e sistemas defensivos. Desse esforço participaram médicos, engenheiros, psicólogos, fisiologistas, entre outros; alguns grupos permaneceram unidos e um deles lançou um novo ramo de pesquisa, denominado de ergonomia. ${ }^{(14)}$

Pode-se afirmar que a concepção da saúde ocupacional no Brasil, do ponto de vista da regulamentação legal, deu-se com a entrada em vigor da Lei $n^{\circ} 6.514^{(15)}$, de 22 de dezembro de 1977, que determinou a nova redação ao Capítulo V da Consolidação das Leis do Trabalho - CLT, "Da Segurança e da Medicina do Trabalho". Neste capítulo, os serviços especializados em segurança e medicina do trabalho estão previstos no Art. 162 consolidado e foram disciplinados pela Norma Regulamentadora - NR-4 da Portaria $n^{\circ} 3.214$, de 8 de junho de 1978. E somente a partir da publicação dessa Portaria estabeleceu-se a obrigatoriedade da participação nos Serviços Especializados em Engenharia de Segurança e em Medicina do Trabalho - o chamado SESMT - dos médicos, engenheiros, enfermeiros, técnicos de segurança no trabalho e auxiliares de enfermagem no trabalho, conforme prevê a NR-4.

No cenário político dos anos 1960, marcado por movimentos sociais que questionavam o sentido da vida, começa a se evidenciar a insuficiência da saúde ocupacional, emergindo a concepção da saúde do trabalhador. Essa vertente utiliza a concepção de classe social e valoriza o trabalhador, deslocando-o da posição de objeto para a de sujeito. Nesse passo, a interdisciplinariedade é revista, já que a pretensão de tratar as doenças com a participação de vários profissionais não alcançou os resultados esperados, e busca-se construir uma relação mais articulada entre os diversos saberes, incluindo o dos trabalhadores. ${ }^{(16)}$

Destaca Sebastião Geraldo de Oliveira que, até a etapa em que predominava o pensamento da saúde ocupacional, o empregado apenas assistia ao desenrolar dos acontecimentos, mas não tinha articulação suficiente para reivindicar, apesar de ser o principal interessado. ${ }^{(17)}$

Cumpre registrar que desde a década de 1970 a concepção doutrinária, refletindo a preocupação dos países ocidentais, passa a ter enfoque mais

(14) Id. Ibid.

(15) BRASIL. Lei ${ }^{\circ} 6.514$, de 22 de dezembro de 1977, Altera o Capítulo V do Titulo II da Consolidação das Leis do Trabalho, relativo a segurança e medicina do trabalho e dá outras providências. Disponível em: <http://www3.dataprev.gov.br/SISLEX/paginas/42/1977/6514.htm>. Acesso em: 2 jul. 2012.

(16) MENDES, René; DIAS, Elizabeth Costa. Da medicina do trabalho à saúde do trabalhador. Revista de Saúde Pública, São Paulo, v. 25, n. 5, p. 341-9, 1991.

(17) op. cit., p. 56 
abrangente, com ênfase na melhora da qualidade de vida do trabalhador, numa perspectiva mais ampla do que sua saúde.

\section{A SAÚDE DO TRABALHADOR NO ÂMBITO INTERNACIONAL E NA LEGISLAÇÃO DO BRASIL}

O advento da OIT foi anteriormente referido; destacou-se sua criação num momento de profundo sofrimento, quando o mundo amargava as consequências da Primeira Grande Guerra; como foi dito, surgiu com a finalidade de promover a justiça social e fazer respeitar os direitos humanos no mundo do trabalho.

Já em plena década de 1970, com a renovação das concepções, ora voltadas à qualidade de vida do trabalho, e paradoxalmente, diante da realidade das condições de trabalho preocupantes, a Conferência Internacional do Trabalho da OIT aprovou resolução instituindo o Programa Internacional para o Melhoramento das Condições e do Meio Ambiente de Trabalho, denominado PIACT, com foco no bem-estar dos trabalhadores, como a principal e permanente missão da OIT. ${ }^{(18)}$

Cumpria definir, diante desse movimento renovatório, o conceito de saúde do trabalhador, que foi formulado na Declaração de Alma-Ata, pela Conferência Internacional sobre Cuidados Primários de Saúde, realizada em 12 de setembro de 1978 e patrocinada pela Organização Mundial da Saúde (OMS) e pela Unicef (Fundo das Nações Unidas para a Infância), que afirmou:

A conferência reafirma enfaticamente que a saúde - estado completo de bem-estar físico, mental e social, e não simplesmente a ausência de doença ou enfermidade - é um direito humano fundamental, e que a consecução do mais alto nível possível de saúde é a mais importante meta social mundial, cuja realização requer a ação de muitos outros setores sociais e econômicos, além do setor da saúde. ${ }^{(19)}$

No que diz respeito ao meio ambiente de trabalho, as Convenções da OIT, ratificadas pelo Brasil, são as de $\mathrm{n}^{\text {os }} 148,152,155$ e 161. Dentre elas, cabe

(18) "La Conferencia Internacional del Trabajo en su 60a reunión (1975), da un paso más mediante la adopción de la resolución sobre la acción futura de la OIT en el campo de las condiciones y del medio ambiente de trabajo. Esta resolución señalaba: "el mejoramiento de las condiciones y del medio ambiente de trabajo y del bienestar de los trabajadores sigue siendo la principal y permanente misión de la OIT ". Después de un proceso formal de consulta con los Estados Membros y las organizaciones nacionales de empleadores y de trabajadores, el Consejo de Administración de la OIT en su reunión de noviembre de 1976, aprueba el diseño general del PIACT." ORGANIZACIÓN INTERNACIONAL DEL TRABAJO. Las actividades de la OIT en el Mundo después de 1945 (Parte 2: 1960-1988). Disponível em: <http://www.ilo.org/public/spanish/support/lib/century/content/1977.htm>. Acesso em: 13 mai. 2011.

(19) ORGANIZAÇÃO PAN-AMERICANA DA SAÚDE. Declaração de Alma-Ata. Alma-Ata, 1978. Disponível em: <http://www.opas.org.br/coletiva/uploadArq/Alma-Ata.pdf>. Acesso em: 2 jul. 2012. 
destacar a Convenção $n^{\circ}$ 155, aprovada em 3 de junho de 1981, com vigência nacional a partir de 18 de maio de 1993, que trata especificamente da segurança e saúde dos trabalhadores, aplica-se a todas as áreas de atividade econômica; prevê que o termo "trabalhadores" abrange todas as pessoas empregadas, incluindo os funcionários públicos (Art. 3, alínea "b").

Essa convenção explicita na alínea "e" do Art. $3^{\circ}$ que

o termo "saúde", com relação ao trabalho, abrange não só a ausência de afecções ou de doenças, mas também os elementos físicos e mentais que afetam a saúde e estão diretamente relacionados com a segurança e a higiene no trabalho. ${ }^{(20)}$

Antes disso, o direito ao meio ambiente de trabalho sadio, como um dos direitos humanos fundamentais no campo do trabalho, já havia sido consagrado no Pacto Internacional dos Direitos Econômicos, Sociais e Culturais de 1966, que assegurava, no seu Art. $7^{\circ}$, o direito de toda pessoa gozar de condições de trabalho justas e favoráveis que assegurem condições de trabalho seguras e higiênicas.

Observe-se que tal previsão já constava da Declaração Universal dos Direitos do Homem, proclamada em 1948 pelas Nações Unidas, quando o mundo ainda vivenciava os horrores da Segunda Guerra:

\section{Art.23}

I) Todo homem tem direito ao trabalho, à livre escolha de emprego, a condições justas e favoráveis de trabalho e à proteção contra o desemprego (grifo nosso).

Merece ser salientada a Convenção $n^{\circ} 161$ da OIT, em vigor no Brasil desde 18 de maio de 1991, que trata dos serviços de saúde no trabalho. No seu preâmbulo, consta que:

a proteção dos trabalhadores contra as doenças profissionais e as doenças em geral e contra os acidentes de trabalho constitui uma das tarefas da Organização Internacional do Trabalho em virtude da sua Constituição.(21)

Importante ressaltar que, para os fins dessa convenção, a expressão os "serviços de saúde do trabalho" designa um serviço investido de funções essencialmente preventivas e encarregado de aconselhar o empregador, os trabalhadores e seus representantes na empresa sobre os requisitos necessários para manter um ambiente de trabalho seguro e salubre, a adaptação do trabalho às capacidades dos trabalhadores, levando em conta seu estado de sanidade física e mental.

A preocupação da OIT com o meio ambiente de trabalho é registrada por Norma Sueli Padilha, exemplificando com a Recomendação $n^{\circ} 164$, de 1981, sobre Seguridade e Saúde dos Trabalhadores e Meio Ambiente do Trabalho, bem como as diversas Convenções e Recomendações a respeito de Substâncias e

(20) SÜSSEKIND. op. cit., p. 392.

(21) SÜSSEKIND. op. cit., p. 407-408. 
Agentes Tóxicos, relembrando que tal Órgão tem editado uma série de orientações, voltadas à proteção dos trabalhadores que se ativam na indústria da edificação, comércio e oficinas, e trabalhos portuários. ${ }^{(22)}$

Nadia Demoliner Lacerda da Silva lembra que a OIT mantém diversos programas internacionais, visando promover uma consciência mundial sobre as dimensões e consequências dos acidentes e doenças ocupacionais, como o "Programa In-Focus (IFP) 'Trabalho Seguro'”, além de projetos em parceria com o Ministério do Trabalho e Emprego (MTE), a Fundacentro e o Serviço Social da Indústria (Sesi). ${ }^{(23)}$

O "Programa In-Focus (IFP) Trabalho Seguro" promove uma consciência mundial sobre as dimensões e consequências dos acidentes, lesões e doenças ocupacionais. Promove também a criação ou melhoria de programas nacionais de proteção básica para todos os trabalhadores, bem como de sistemas integrados de gestão de segurança e saúde no trabalho. ${ }^{(24)}$

\section{A legislação sanitária em saúde do trabalhador no Brasil}

Desde a promulgação da Constituição Federal de 1988, reconhecidamente uma constituição cidadã, a linha de proteção à saúde ganhou contornos de direito fundamental. O Art. $6^{\circ}$ estabeleceu como direitos sociais obrigatoriamente garantidos pelo Estado, pelos Poderes Executivo, Legislativo e Judiciário, a educação, a saúde, o trabalho, a moradia, o lazer, a segurança, a previdência social, a proteção à maternidade e à infância, a assistência aos desamparados. (grifei)

E ao tratar do Sistema Único de Saúde, a Carta Maior prevê, no Art. 200, que ao SUS compete, dentre outras atribuições:

II) executar as ações de vigilância sanitária e epidemiológica, bem como as de saúde do trabalhador;

(...) VIII - colaborar na proteção ao meio ambiente, nele compreendido o do trabalho.

Ressalte-se que a implantação do Sistema Único de Saúde (SUS) foi calcada na Lei Orgânica da Saúde, Lei n 8.080/90(25) e em várias Constituições Estaduais e Municipais.

(22) PADILHA, Norma Sueli. Do meio ambiente do trabalho equilibrado. São Paulo : LTr, 2002. p. 96. (23) SILVA, Nadia T. Demoliner Lacerda da. Negociação coletiva e o meio ambiente do trabalho. In: SANTOS, Enoque Ribeiro do; SILVA, Otavio Pinto e (Coord.). Temas controvertidos do direito coletivo do trabalho no cenário nacional e internacional. São Paulo: LTr, 2006. p. 245-254.

(24) CUNHA NETO, Hugo Leonardo da; FIGUEIREDO, Rúbia Thaís de; SOARES, Thayara Rejane Reis. OIT - Organização Internacional do Trabalho. Disponível em: <http://www.ebah.com.br/content/ ABAAAA3ikAB/oit>. Acesso em: 13 maio 2011.

(25) BRASIL. Lei $n^{\circ} 8.080$, de 19 de setembro de 1990, Dispõe sobre as condições para a promoção, proteção e recuperação da saúde, a organização e o funcionamento dos serviços correspondentes e dá outras providências. Disponível em: <http://www.planalto.gov.br/ccivil_03/Leis/L8080.htm>. Acesso em: 2 jul. 2012. 
Raimundo Simão de Melo salienta que o Brasil, em termos de legislação ambiental, inclusive na seara do meio ambiente do trabalho, é um dos países mais avançados do mundo. ${ }^{(26)}$ Assim, o arcabouço é composto pela Constituição Federal de 1988, que influenciou várias Constituições estaduais que seguiram a mesma linha, dentre elas a do Estado de São Paulo; bem como pela Lei de Política Nacional do Meio Ambiente (Lei $n^{\circ} 6.938 / 91^{(27)}$ ); pelo Capítulo V da Consolidação das Leis do Trabalho - CLT, alterado em 1977 pela Lei $n^{\circ}$ 6.514/77; e pela Portaria $n^{\circ} 3.214 / 78^{(28)}$ e suas várias Normas Regulamentadoras. Somam-se a esse arcabouço legal as convenções coletivas de trabalho e sentenças normativas proferidas pela Justiça do Trabalho nos Dissídios Coletivos, fruto das reivindicações que passaram a constar das pautas dos sindicatos dos trabalhadores.

Saliente-se que, no estado de São Paulo, a Constituição Estadual, o Código de Saúde (Lei Complementar $n^{\circ} 791 / 95^{(29)}$ ) e o Código Sanitário (Lei $n^{\circ} 10.083 / 98^{(30)}$ ) determinam a atuação sobre os fatores ou situações de risco encontrados nos ambientes e processos produtivos de trabalho. Destaque-se ainda a importância da Lei $n^{\circ} 9.505 / 97^{(31)}$, que disciplina as ações e os serviços de saúde dos trabalhadores no Sistema Único de Saúde estadual.

Verifica-se, assim, a atenção estatal, como foco no aumento da visibilidade social do adoecimento ocupacional. Nessa linha, a implantação dos Centros de Referência em Saúde do Trabalhador (Cerest), de abrangência regional e em todo o país, com as seguintes atribuições, de acordo com o Ministério da Saúde:

capacitar a rede de serviços de saúde, apoiar as investigações de maior complexidade, assessorar a realização de convênios de cooperação técnica, subsidiar a formulação de políticas públicas, apoiar a estruturação da assistência de média e alta complexidade para atender aos acidentes de trabalho e agravos contidos na Lista de Doenças Relacionadas ao Trabalho e aos agravos

(26) MELO, Raimundo Simão de. Direito ambiental do trabalho e a saúde do trabalhador. São Paulo: LTr, 2008. p. 30.

(27) BRASIL. Lei $n^{\circ} 6.938$, de 31 de agosto de 1991, Dispõe sobre a Política Nacional do Meio Ambiente, seus fins e mecanismos de formulação e aplicação, e dá outras providências. Disponível em: <http://www.planalto.gov.br/Ccivil_03/Leis/L6938compilada.htm>. Acesso em: 2 jul. 2012.

(28) BRASIL. Ministério do Trabalho. Portaria $n^{\circ} 3.214$, de 8 de junho de 1978, Aprova as Normas Regulamentadoras - NR - do Capítulo V, Título II, da Consolidação das Leis do Trabalho, relativas a Segurança e Medicina do Trabalho. Disponível em: <http://www3.dataprev.gov.br/sislex/paginas/63/ mte/1978/3214.htm>. Acesso em: 2 jul. 2012.

(29) SÃO PAULO (Estado). Lei complementar $n^{\circ} 791$, de 9 de março de 1995, Estabelece o Código de Saúde no Estado. Disponível em: <http://www.al.sp.gov.br/repositorio/legislacao/lei\%20 complementar/1995/lei\%20complementar\%20n.791,\%20de\%2009.03.1995.htm>. Acesso em: 2 jul, 2012.

(30) SÃO PAULO. Lei Estadual $n^{\circ} 10.083$, de 23 de setembro de 1998, Dispõe sobre o Código Sanitário do Estado. Disponível em: <http://www.prefeitura.sp.gov.br/cidade/secretarias/upload/ LeiEstadual_1998_10083_1254945304.pdf>. Acesso em: 2 jul.2012.

(31) SÃO PAULO. Lei Estadual n 9.505, de 11 de março de 1997, Disciplina as ações e os serviços de saúde dos trabalhadores no Sistema Único de Saúde. Disponível em: <http://www.jusbrasil.com. br/legislacao/171814/lei-9505-97-sao-paulo-sp>. Acesso em: 2 jul. 2012. 
de notificação compulsória citados na Portaria GM/MS n 777 de 28 de abril de 2004 (32) $^{(32}$

Os Centros Estaduais e Regionais de Referência em Saúde do Trabalhador (Cerest) compõem a Rede Nacional de Atenção Integral à Saúde do Trabalhador (Renast); atualmente são 210 Cerest e somam-se a uma rede de serviços do SUS, voltada ao diagnóstico dos acidentes e doenças relacionados ao trabalho e por registrá-los no Sistema de Informação de Agravos de Notificação (Sinan-NET). ${ }^{(33)}$

Uma das diretrizes da Política Nacional de Saúde do Trabalhador do Ministério da Saúde prevê que "a Renast responde pela execução de ações curativas, preventivas, de promoção e de reabilitação à saúde do trabalhador brasileiro". ${ }^{(34)}$

É inegável que houve evolução; atualmente há estrutura pública de atenção à saúde do trabalhador que antes não existia; cumpre examinar se isso é suficiente, para tornar visíveis as causas de adoecimento relacionado ao trabalho.

Impõe-se questionar, com o arcabouço legal atualmente em vigor, se o respeito às normas de proteção à saúde e à segurança dos trabalhadores é praticado e incentivado por todos, empregadores e até mesmo pelo poder público.

É o que procuraremos responder.

\section{A DISTÂNCIA ENTRE O DIREITO E O RESPEITO À SAÚDE DO TRABALHADOR}

\section{As mudanças no mundo do trabalho}

Ensina Ricardo Antunes, em seu estudo sobre sociologia industrial, que o capital, em resposta à sua crise estrutural, intensificou

transformações no próprio processo produtivo, por meio do avanço tecnológico, da constituição das formas de acumulação flexível e dos modelos alternativos ao binômio taylorismo/fordismo, onde se destaca, para o capital, especialmente, o toyotismo. ${ }^{(35)}$

(32) BRASIL. Ministério da Saúde. Portal da Saúde. Centro de Referência em Saúde do Trabalhador Disponível em: <http://portal.saude.gov.br/portal/saude/visualizar_texto.cfm?idtxt=30427\&janela=1>. Acesso em: 21 dez. 2011.

(33) BRASIL. Ministério da Saúde. Portal da Saúde. Portaria amplia número de Centros de Saúde do Trabalhador.Disponível em: <http://portalsaude.saude.gov.br/portalsaude/noticia/3771/162/portariaamplia-numerode-centros-de-saude-do-trabalhador.html>. Acesso em: $21 \mathrm{dez} .2011$.

(34) BRASIL. Ministério da Saúde. Portal da Saúde. Rede Nacional de Atenção à Saúde do Trabalhador. Disponível em: <http://portal.saude.gov.br/portal/saude/visualizar_texto.cfm?idtxt=25085\&janela=1 >. Acesso em: $21 \mathrm{dez} .2011$.

(35) ANTUNES, Ricardo. Adeus ao trabalho? Ensaio sobre as metamorfoses e a centralidade do mundo do trabalho. São Paulo: Cortez, 2010. p. 195. 
Esse autor destaca que essa forma flexibilizada de acumulação capitalista baseada na reengenharia, na empresa enxuta, teve consequências enormes no mundo do trabalho, e elenca as mais importantes:

1) Há uma crescente redução do proletariado fabril estável, que se desenvolveu na vigência do binômio taylorismo/fordismo e que vem diminuindo com a reestruturação, flexibilização; (...)

2) Há um enorme Incremento do novo proletariado, do subproletariado fabril e de serviços, o que tem sido denominado mundialmente de trabalho precarizado. São os terceirizados, subcontratados; (...)

3) Vivencia-se um aumento significativo do trabalho feminino (...) absorvido pelo capital no universo do trabalho precarizado e desregulamentado; (...)

4) (...);

5) Há exclusão dos jovens e idosos do mercado de trabalho dos países centrais; (...)

6) Há uma inclusão precoce e criminosa de crianças no mercado de trabalho (...). (36)

Analisando a atual conjuntura, as transformações no modelo de produção capitalista, afirma que sob o capitalismo não se constata o fim do trabalho, mas sua mudança qualitativa:

(...) Nesse sentido, desregulamentação, flexibilização, terceirização, downsizing, "empresa enxuta", bem como todo esse receituário que se esparrama pelo "mundo empresarial", são expressões de uma lógica societal onde se tem a prevalência do capital sobre a força humana de trabalho, que é considerada somente na exata medida em que é imprescindível para a reprodução desse mesmo capital. Isso porque o capital pode diminuir o trabalho vivo, mas não eliminá-lo. Pode intensificar sua utilização, pode precarizá-lo e mesmo desempregar parcelas imensas, mas não pode extingui-lo. (...). ${ }^{(37)}$

Otavio Pinto e Silva, enfocando tal questão, afirma que o processo de globalização da economia, somado às mudanças tecnológicas, resultam na adoção de diversas formas de reestruturação produtiva; geram novas profissões, ao mesmo tempo em que levam ao desaparecimento de outras. Enfoca que o emprego deixa de ser a relação jurídica hegemônica e chama a atenção para as alterações no mundo do trabalho:

(...) Em todo o mundo assiste-se à fragmentação do mercado de trabalho e à elevação do desemprego, fenômenos que estão associados ao surgimento de novas figuras contratuais, ao lado do tradicional contrato de trabalho por prazo indeterminado. (...) $)^{(38)}$

Assim, salienta esse autor, as mudanças que marcaram o final do século XX levaram ao surgimento de novas modalidades de trabalho; destaca a noção

(36) ANTUNES, Ricardo. op. cit., p. 197-198.

(37) ANTUNES, Ricardo. op. cit., p. 199.

(38) SILVA, Otavio Pinto e. Subordinação, autonomia e parassubordinação nas relações de trabalho. São Paulo: LTr, 2004. p. 9. 
de parassubordinação, desenvolvida pelo direito italiano; diz que a tipificação legislativa do trabalho "coordenado" é vista como oportuna e necessária na Itália.

No Brasil, adverte, a simples inserção de um grande número de direitos trabalhistas na Constituição ou normas infraconstitucionais não basta para garantir a tutela dos trabalhadores.

No nosso país, o acesso dos trabalhadores aos direitos só é possível mediante a contratação formal. Chama a atenção para a realidade dos trabalhadores na economia informal, para a divisão entre "incluídos" e "excluídos", salientando:

(...) O objetivo é substituir as antigas formas de regulação por outras, novas, em harmonia com as metas de produtividade, competitividade e estabilidade econômica, mas inseridas em uma política de preservação dos direitos humanos fundamentais que a Organização Internacional do Trabalho denomina de acesso a um "trabalho decente".

Não se trata simplesmente de criar postos de trabalho, uma vez que estes precisam ser de qualidade aceitável. (...). (39)

Para alguns, as transformações havidas com o processo de globalização da economia e em especial as mudanças imprimidas pelas inovações tecnológicas significaram dinamização do trabalho, maior eficiência, "qualidade total", por força de um senso comum de que tais alterações são frutos da modernidade e de que tudo o que é moderno é bom. Mais uma vez, cabe aos que se preocupam com o mundo do trabalho, não voltado somente à acumulação do capital, mas à qualidade de vida do trabalhador, questionar se tais inovações foram positivas para os trabalhadores.

\section{Do que adoecem os trabalhadores na atualidade}

Ressaltamos no item anterior que as novas tecnologias e a chamada reengenharia resultaram na redução dos postos de trabalho no setor fabril, ao mesmo tempo em que houve incremento no setor de serviços.

Tomemos como exemplo o setor financeiro: na primeira metade do século $X X$, os bancários eram acometidos por tuberculose e por transtornos psíquicos denominados na época de "psiconeurose bancária", que fundamentou a redução de jornada do bancário para seis horas diárias.

Mudanças significativas atingiram o setor, sobretudo a partir dos anos 1980 e 1990, com consequências diversas e negativas, como segmentação da clientela por faixas de renda, sobrecarga de trabalho, o prolongamento das jornadas, a automação do sistema, a fragmentação das tarefas e a pressão por cumprimento de metas, as quais passaram a provocar entre os trabalhadores bancários quadros clínicos de dor do sistema musculoesquelético.

(39) SILVA. op. cit., p. 193-194. 
Assim, concomitantemente às enfermidades clássicas decorrentes do processo de trabalho, como pneumoconioses e intoxicações, manifestações mais complexas de adoecimento passaram a ter visibilidade entre os trabalhadores. É o caso das Lesões por Esforços Repetitivos (LER), atualmente denominadas Distúrbios Osteomusculares Relacionados ao Trabalho (DORT), identificadas no Brasil na década de 1970, destacam Maria Maeno e José Carlos do Carmo. ${ }^{(40)}$ A Ordem de Serviço ${ }^{\circ} 606 / 1998$ da DSS do INSS mencionava que a primeira referência no Brasil ocorreu no ano de 1973, por ocasião do XII Congresso Nacional de Prevenção de Acidentes do Trabalho, quando foram descritos casos de tenossinovite ocupacional em lavadeiras, limpadoras e engomadeiras; a OS $n^{\circ} 606$ foi revogada pela Instrução Normativa n 98/2003 do INSS, que também tem como objeto as LER/DORT.

Afirmam Maria Maeno e José Carlos do Carmo que inicialmente tais moléstias foram diagnosticadas como tendinites e tenossinovites, e a partir de 1986 passaram a ser reconhecidas como doenças de origem ocupacional. Tanto no Instituto Nacional do Seguro Social (INSS) como no sistema de saúde, o reconhecimento como agravo relacionado ao trabalho foi gradativo, decorrente da ativa participação de profissionais da saúde, dos Centros de Referência de Saúde do Trabalhador (Cerest) e do movimento sindical.

Assim veio o reconhecimento da "tenossinovite do digitador" e outras lesões por esforços repetitivos como doença do trabalho, por intermédio da Portaria do Ministério da Previdência e Assistência Social $n^{\circ}$ 4.062, de 6 de agosto de 1987.

A denominação LER/DORT é genérica e engloba várias espécies de doenças do sistema musculoesquelético, de origem ocupacional, catalogadas na literatura médica, como: tenossinovite de De Quervain, tenossinovite dos extensores dos dedos, epicondilites, bursites, tendinite do supraespinhoso ou da porção longa do bíceps, dedo em gatilho, síndrome do túnel do carpo, síndromes miofasciais, fibromialgias, cervicobraquialgias etc.

Ressalte-se que LER e DORT são considerados sinônimos no Brasil, de acordo com a legislação da Previdência Social (Instrução Normativa ${ }^{\circ}$ 98/2003) e a legislação sanitária. Assim, denominam-se Doenças Relacionadas ao Trabalho (DORT), conforme Manual de procedimentos para os serviços de saúde de 2001; Protocolo de LER/DORT de 2006 do Ministério da Saúde e Portaria $n^{\circ} 104 / 11$ desse Ministério, que revogou a Portaria $n^{\circ} 777 / 04$, dessa pasta; registre-se que em 2012 foi lançado um Protocolo de LER/DORT pelo

(40) MAENO, Maria; CARMO, José Carlos do. Saúde do Trabalhador no SUS: aprender com o passado, trabalhar o presente, construir o futuro. São Paulo: Hucitec, 2005. p. 123. 
Ministério da Saúde. ${ }^{(41)}$ Reconheça-se que se trata de legislação importante, no cenário em que tem se tentado aumentar a visibilidade social do adoecimento ocupacional.

Observe-se que a designação LER/DORT não serve como diagnóstico; é preciso que a moléstia receba diagnóstico específico do médico. No entanto, o diagnóstico da entidade nosológica (tendinites, tenossinovites etc.) não confere o caráter ocupacional, que deve ser reconhecido sobretudo por quem conhece o trabalho. Assim, o estabelecimento do nexo de causalidade com o trabalho é feito por equipes multidisciplinares de vigilância em ambientes de trabalho. $\mathrm{Na}$ Previdência Social, a relação causal é estabelecida pelo perito do INSS e, nos casos de processos judiciais, os peritos do juízo têm a função de apontar a existência do caráter ocupacional.

Ensinam as professoras Ada Ávila Assunção e Lailah Vilela que a denominação LER é um termo guarda-chuva que abriga várias doenças descritas na literatura médica. ${ }^{(42)}$

As moléstias elencadas constam das listas de agravos ocupacionais do Ministério da Saúde e do Ministério da Previdência Social, previstos respectivamente na Portaria $n^{\circ} 1.339 / 99^{(43)}$ e no Decreto $n^{\circ} 3.048 / 99 .{ }^{(44)}$

De qualquer forma, a falta de comunicação dessas doenças do trabalho dificulta as ações de vigilância e de recuperação da saúde dos trabalhadores, em especial nos casos de adoecimento coletivo:

(...) aos agravos à saúde dos trabalhadores, tem disseminado novos desafios, pois condições e ambientes de trabalho historicamente considerados prejudiciais e, portanto, origem dos acidentes e doenças ocupacionais clássicas, têm com a globalização econômica, ampliado muitos males (invisíveis) que atingem os trabaIhadores. As Lesões por Esforço Repetitivo (LER) e as Doenças Osteomusculares Relacionadas ao Trabalho (DORT) são algumas dessas expressões, mas nem sempre consideradas vinculadas ao trabalho. Ao não serem diagnosticadas como relacionadas ao trabalho, também não são notificadas e ficam na invisibilidade social o que, via de regra, prejudica a organização de ações e serviços de vigilância e de recuperação da saúde dos sujeitos que adoecem coletivamente, mas, em decorrência do tratamento individualizado e distante das causas, acabam ficando

(41) BRASIL. Ministério da Saúde. Dor relacionada ao trabalho: lesões por esforços repetitivos (LER): distúrbios osteomusculares relacionados ao trabalho (Dort). Brasília: Editora MS, 2012. Disponível em: <http://bvsms.saude.gov.br/bvs/publicacoes/dor_relacionada_trabalho_ler_dort.pdf>. Acesso em: 29 maio 2012.

(42) ASSUNÇÃO, Ada Ávila; VILELA, Lailah Vasconcelos Oliveira. Lesões por esforços repetitivos: guia para profissionais de saúde. Piracicaba: Cerest, 2009. p. 14.

(43) BRASIL. Ministério da Saúde. Portaria $n^{\circ} 1.339$, de 18 de novembro de 1999. Disponível em: <http://www.cerest.rn.gov.br/contentproducao/aplicacao/sesap_cerest/legislacao/gerados/portaria\%20 federal\%201.339.pdf>. Acesso em: 16 maio 2011.

(44) BRASIL. Decreto ${ }^{\circ} 3.048$, de 6 de maio de 1999, Aprova o Regulamento da Previdência Social, e dá outras providências. Disponível em: <http://www010.dataprev.gov.br/sislex/paginas/23/1999/3048. htm>. Acesso em: 2 jul. 2012. 
no anonimato. Assim, discute-se (...) as implicações da falta de notificação dos agravos relacionados ao trabalho para a elaboração e efetivação das políticas mais amplas de atenção à saúde e de prevenção destes problemas. ${ }^{(45)}$

Cabe salientar que, assim como ocorreu com as LER/DORT nos anos 1980 e 1990, atualmente os transtornos psíquicos destacam-se como moléstias que acometem grande número de trabalhadores; no entanto, a caracterização das doenças musculoesqueléticas ocupacionais continua sendo predominante.

Segundo Duílio de Camargo, médico do trabalho e psiquiatra do Hospital das Clínicas de São Paulo, na década de 1970 destacava-se a incidência dos acidentes típicos; na década de 1980, a perda auditiva induzida por ruído; na década de 1990, as doenças osteomusculares e, atualmente, os transtornos mentais. O número de trabalhadores que receberam auxílio doença acidentário no Brasil, em razão de adoecimentos relacionados direta ou indiretamente ao estresse, cresceu acentuadamente em três anos. ${ }^{(46)}$

Sebastião Geraldo de Oliveira explicita, em relação ao estresse:

Na avaliação da OIT, o estresse é um dos mais graves problemas de saúde da atualidade, que só nos Estados Unidos tem um custo superior a 200 bilhões de dólares por ano, representando dez vezes mais do que o custo de todas as greves reunidas, enquanto, no Reino Unido, a previsão é de que o custo do estresse atinja $10 \%$ do PNB. No Japão, o psiquiatra Tetsunojo Uehata, que criou o vocábulo "karoshi" - morte causada pelo excesso de trabalho -, informou, em 1992, que os problemas do estresse quadruplicaram em dez anos. ${ }^{(47)}$

Esse autor, referindo-se à aceleração do ritmo do trabalho nos dias atuais, afirma:

(...) Essa mudança ou aceleração, apesar de ter promovido uma revolução na produtividade, está repercutindo negativamente na saúde física e mental dos trabalhadores, provocando conflitos, afastamentos do trabalho, adoecimentos ou até invalidez total. Como consequência, também gera redução da produtividade, problemas no gerenciamento de pessoal, demandas judiciais e desembolsos com indenizações (...). (48)

Definida por alguns autores como uma das consequências mais marcantes do estresse profissional, a chamada Síndrome de Burnout tem as seguintes características:

(...) exaustão emocional, avaliação negativa de si mesmo, depressão e insensibilidade com relação a quase tudo e todos (até como defesa emocional). (...)

(45) LOURENÇO, Edvânia Ângela de Souza; BERTANI, Iris Fenner. Invisibilidade social das doenças relacionadas ao trabalho: desafios para a reabilitação profissional. In: SEMINARIO DE SAUDE DO TRABALHADOR DE FRANCA, 2010, Franca. Anais eletrônicos... Unesp Franca, Disponível em: $<$ http://www.proceedings.scielo.br/scielo.php?script=sci_arttext\&pid=MSC000000011201000010002 0\&lng=pt\&nrm=abn>. Acesso em: 2 jul. 2012.

(46) OLIVEIRA. op. cit., p. 180.

(47) OLIVEIRA. op. cit., p. 179.

(48) OLIVEIRA. op. cit., p. 180. 
Como síndrome, o burnout seria o resultado da combinação entre as características individuais do paciente com as condições do ambiente ou do trabalho, o qual geraria excessivos e prolongados momentos de estresse no trabalho. Essa síndrome se refere a um tipo de estresse ocupacional e institucional com predileção para profissionais que mantêm uma relação constante e direta com outras pessoas, principalmente quando esta atividade é considerada de ajuda (médicos, enfermeiros, professores).

De fato, esta síndrome foi observada, originalmente, em profissões predominantemente relacionadas a um contacto interpessoal mais exigente, tais como médicos, psicanalistas, carcereiros, assistentes sociais, comerciários, professores, atendentes públicos, enfermeiros, funcionários de departamento pessoal, telemarketing e bombeiros. Hoje, entretanto, as observações já se estendem a todos profissionais que interagem de forma ativa com pessoas, que cuidam e/ou solucionam problemas de outras pessoas, que obedecem técnicas e métodos mais exigentes, fazendo parte de organizações de trabalho submetidas à avaliações. (...).(49)

E no estudo sobre outro transtorno mental, a depressão, observada no meio ambiente de trabalho e sua caracterização como doença de origem ocupacional, Sueli Teixeira destaca que o estabelecimento do nexo causal dessa moléstia com o trabalho tem suscitado polêmica e produzido entendimentos judiciais divergentes. Ressalta, dentre os transtornos psíquicos, a depressão e as dificuldades existentes para sua vinculação com o trabalho, especialmente devido às várias influências e fatores diversos, ligados à natureza humana e que também podem contribuir para a eclosão da moléstia. ${ }^{(50)}$

É importante ressaltar que o Decreto $n^{\circ} 3.048$, que aprova o Regulamento da Previdência Social, elenca no seu Anexo II as doenças do trabalho e inclui hipóteses de reconhecimento do estresse, da depressão, bem como da "Sensação de Estar Acabado ("Síndrome de Burn-Out", "Síndrome do Esgotamento Profissional"), como doenças de origem ocupacional.

No entanto, de acordo com o Decreto $n^{\circ} 3.049 / 99$ a depressão ocupacional tinha que ser relacionada à exposição de substâncias químicas; somente com o advento do Nexo Técnico Epidemiológico Previdenciário (NTEP), instituído pela Lei $n^{\circ} 11.430^{(51)}$, de 26 de dezembro de 2006, que alterou a Lei $n^{\circ} 8.213$, de 24 de julho de 1991, é que a depressão relacionada a aspectos da organização do trabalho, dentre outros, foi reconhecida.

(49) BALLONE, G. J. Síndrome de Burnout. In: PsiqWeb. Revisto em 2009. Disponível em: <www. psiqweb.med.br>. Acesso em: 12 jul. 2012.

(50) TEIXEIRA, Sueli. A depressão no meio ambiente do trabalho e sua caracterização como doença do trabalho. Revista LTr, São Paulo, v. 73, n. 5, 527-536, 2009.

(51) BRASIL. Lei $n^{\circ} 11.430$, de 26 de dezembro de 2006, Altera as Leis $n^{\circ} 8.213$, de 24 de julho de 1991, e 9.796, de 5 de maio de 1999, aumenta o valor dos benefícios da previdência social; e revoga a Medida Provisória $n^{\circ} 316$, de 11 de agosto de 2006; dispositivos das Leis nos 8.213, de 24 de julho de 1991, 8.444, de 20 de julho de 1992, e da Medida Provisória ${ }^{\circ}$ 2.187-13, de 24 de agosto de 2001; e a Lei $n^{\circ}$ 10.699, de 9 de julho de 2003. Disponível em: <http://www.planalto.gov.br/ccivil_03/_Ato20042006/2006/Lei/L11430.htm>. Acesso em: 2 jul. 2012. 
Sueli Teixeira afirma que, segundo estatísticas da Previdência Social, os transtornos mentais ocupam a terceira posição entre as causas de concessão de benefícios previdenciários e destaca como tais moléstias afetam os trabaIhadores, por ramo de atividade:

(...). O levantamento dos dados aponta os ramos de atividade que apresentam mais casos de afastamento por transtornos mentais: extração de petróleo, atividades imobiliárias, transporte aéreo, captação, tratamento e distribuição de água e fabricação de produtos têxteis, levando à conclusão de que, dependendo da ocupação, os riscos aumentam. Somam-se ainda as frequentes vítimas de assaltos nos locais de trabalho; bancários e comerciantes também figuram entre as categorias mais afetadas pelos distúrbios mentais, além dos profissionais do ensino e policiais.

Uma pesquisa da Universidade de Brasília (UnB) em parceria com a Previdência Social demonstra que o número de trabalhadores com problemas mentais vem aumentando nos últimos anos. Bancários, frentistas, trabalhadores do comércio, metalúrgicos, rodoviários e transportadores aéreos estão entre as categorias de maior risco. No levantamento, $48,8 \%$ dos trabalhadores que se afastam por mais de 15 dias do serviço sofrem algum tipo de doença mental. (...). (52)

Exemplo peculiar dentre as novas atividades e novas formas de relações de trabalho no mundo atual é o teleatendimento ou telemarketing, que teve início no Brasil no final de década de 1970, mas seu crescimento deu-se somente na década seguinte; com a expansão da informática, o atendimento vem ganhando rapidez e acúmulo de informações, possibilitando um atendimento mais "personalizado".

Pesquisadores do Instituto de Psicologia da Universidade de São Paulo realizaram estudo sobre as dimensões psicossociais no trabalho de teleatendimento, a partir de visita à empresa desse setor e de entrevistas com alguns de seus ex-operadores. De início, destacaram a posição do cliente, aquele que está "do lado de cá da linha"; isto é, para nós, clientes, as condições de trabalho dos operadores de telemarketing são invisíveis; importa para aquele que atende o telefone tão somente não ser incomodado e não perder tempo:

(...) Para nós, que até então conhecíamos apenas "o lado de cá da linha", como clientes, o serviço de teleatendimento era percebido como algo inconveniente, por invadir nossa privacidade, em nossas casas, por meio de ligações telefônicas e, quando acionávamos esse serviço, por nem sempre conseguíamos ter nossos problemas resolvidos. (...)(53)

Nas entrevistas realizadas por esses pesquisadores com os operadores de teleatendimento, várias patologias ou sintomas foram referidos por esses trabalhadores, como tendinite, problemas na coluna, problemas gástricos, infecção urinária, rouquidão, dentre outros, e tanto estresse quanto depressão foram ressaltados:

(52) TEIXEIRA. op. cit., p. 528.

(53) RAMALHO, Carolina Calmon et al. Viver na baia: dimensões psicossociais da saúde e do controle no trabalho de teleatendimento. Cadernos de Psicologia Social e do Trabalho, São Paulo, v. 11, n. 1, p. 19-39, 2008. 
(...) O termo "estresse" é empregado pelos entrevistados para identificar o sofrimento ligado à pressão da rotina, da gerência e das metas e à impossibilidade de responder às necessidades dos clientes, enquanto o termo "depressão" é empregado para qualificar a vivência relativa à falta de perspectiva, à impossibilidade de mudança no trabalho, de função e mesmo de atividade. (...) (54)

Fruto de processo de desgaste relacionado às exigências do trabalho, materializadas por meio de cumprimento de metas cada vez mais inatingíveis, determinação para realização de vendas de produtos independentemente das necessidades dos clientes, sobrecarga laboral, constrangimentos, humilhações, discriminação, impedimento de gozo de pausas intrajornada, controle até quanto à realização das necessidades fisiológicas, somados à terceirização e precarização do trabalho, as manifestações clínicas de transtornos psíquicos no trabalho de teleatendimento são cada vez maiores.

Recentemente, na sessão do Pleno do Tribunal Superior do Trabalho (TST), realizada em 24 de maio de 2011, foi aprovada uma série de mudanças em sua jurisprudência e, dentre elas, uma alteração veio em benefício dos operadores de telemarketing, vez que a Orientação Jurisprudencial n 273 da Seção Especializada em Dissídios Individuais - Subseção I (SDI-1) do TST foi cancelada, significando, com isso, que a esses trabalhadores passa a ser aplicado o disposto no Art. 227 da CLT, que estabelece "jornada máxima de seis horas contínuas de trabalho por dia ou trinta e seis horas semanais".

Trata-se de um avanço, de medida protetiva à saúde dos trabalhadores em teleatendimento. No entanto, não basta a redução da jornada; é preciso atentar também para o processo de organização do trabalho, fator importante de adoecimento.

Estudo realizado por Selma Venco, no qual as centrais de atendimento são denominadas como "a fábrica do século XIX nos serviços do século XXI", demonstra que o problema não se limita à jornada:

Pode-se analisar a intensificação do trabalho por dois ângulos: o da eliminação dos tempos mortos entre as tarefas, suprimindo-se o período de recuperação dos trabaIhadores ou sobrepondo-se tarefas, e o aumento de sua velocidade de execução. ${ }^{(55)}$

No que tange ao processo de organização do trabalho, destaque-se que as portarias 8 e 9 da NR 17 (Portaria $n^{\circ}$ 3.214/78) tratam dos trabalhadores caixas e de operadores de teleatendimento, respectivamente; e que a NR 17 é a única norma que enfoca a organização do trabalho.

O liame entre o processo de organização do trabalho e a doença mental é feito de forma brilhante por Christophe Dejours, no capítulo em que trata do "sofrimento invisível":

(54) RAMALHO. op. cit., p. 33.

(55) VENCO, Selma. Centrais de atendimento: a fábrica do século XIX nos serviços do século XXI. Revista de Saúde Ocupacional, São Paulo, v. 31, n. 114, jul/dez. 2006. p. 10. 
(...) Veremos a seguir como a organização do trabalho é, indubitavelmente, a causa de certas descompensações. Esse fenômeno pode ser observado, a mínima, em duas circunstâncias, que nos servirão aqui como exemplos. A primeira concerne ao aumento dos ritmos de trabalho na indústria eletrônica. (...) Os autores de um relatório sobre a análise do trabalho nesse ramo industrial mostram que o aumento da cadência, a aceleração dos tempos e a exigência de desempenhos produtivos de rendimento crescente conduzem a descompensações rápidas, que se desencadeiam como epidemias. (...)

Basta diminuir a pressão organizacional para fazer desaparecer toda manifestação do sofrimento. (...). ${ }^{(56)}$

Nesse passo, reitera-se o questionamento: da Revolução Industrial até o século XXI, houve inegável evolução e o reconhecimento do direito à saúde do trabalhador; contudo, há efetiva preocupação, nos dias de hoje, com a saúde e segurança dos trabalhadores, por parte dos empregadores, do poder público e até mesmo dos consumidores? Essa é uma questão "visível" para a sociedade?

Vivenciamos a evolução cada vez mais célere de novas tecnologias; há eclosão de "novas" moléstias, com origem ocupacional reconhecida. E nesse quadro, será que os acidentes de trabalho, os chamados "acidentes tipo", diminuíram?

A resposta pode ser dada por meio da transcrição do manifesto do Diretor Geral da Oficina Internacional do Trabalho da OIT, efetuado em 28 de abril de 2011, Dia Mundial da Segurança e Saúde no Trabalho:

En este Día recordamos que, cada año, alrededor de 337 millones de personas son víctimas de accidentes del trabajo y más de 2,3 millones de personas mueren debido a accidentes o a enfermedades profesionales. Ya sea en las minas o en las plantas químicas, en las oficinas o en los campos, los accidentes y enfermedades profesionales causan más víctimas, tanto mortales como en términos de discapacidad, que pandemias mundiales como el VIH y el sida o la tuberculosis.

Acontecimientos dramáticos como el accidente nuclear de la central japonesa de Fukushima este año o el accidente minero de Pike River acaecido el pasado año en Nueva Zelandia son objeto de grandes titulares. Sin embargo, la mayoría de los accidentes, enfermedades y muertes relacionados con el trabajo pasan desapercibidos y no se informa de ellos. Los trabajadores y sus familias suelen quedar sin protección ni ayuda para hacerles frente. ${ }^{(57)}$

O cenário mundial nos é revelado pela própria OIT, por meio de seu Diretor Geral, que ressalta que os acidentes, doenças e mortes passam despercebidos.

(56) DEJOURS, Christophe. A loucura do trabalho. São Paulo: Cortez-Oboré, 1988.

(57) ORGANIZAÇÃO INTERNACIONAL DO TRABALHO. Oficina Internacional del Trabajo. Ofi cina del Director General. Mensaje de Juan Somavia, Director General de la Ofi cina Internacional del Trabajo, con ocasión del Día Mundial de la Seguridad y Salud en el Trabajo. Disponível em: <http:// www.ilo.org/public/spanish/bureau/dgo/speeches/somavia/2011/osh.pdf>. Acesso em: 9 jun. 2011. 
No Brasil, de acordo com a $19^{a}$ edição do Anuário Estatístico da Previdência Social (AEPS), disponível no sítio do Ministério da Previdência Social, houve uma diminuição dos acidentes de trabalho em 2010 com relação a 2009; contudo, o número de trabalhadores que perderam a vida por acidente de trabalho aumentou no último ano.

Segundo o Anuário, em 2010 foram registrados 701.496 acidentes contra 723.452 em 2009; apesar disso, foram registradas 2.712 mortes no último ano, das quais em 2009 foram registradas 2.560 .

De um modo geral, o número de acidentes foi menor no ano passado em relação aos anteriores. Foram 525.206 com Comunicação de Acidente de Trabalho (CAT) registrada, sendo 414.824 acidentes típicos e 15.593 relacionados a doenças ocupacionais, enquanto no caso dos acidentes de trajeto houve elevação, saltando de 90.180 em 2009 para 94.789 casos em 2010. O número de acidentes sem CAT registrada também foi mais baixo, 176.290.

Em todas as regiões do país a quantidade de acidentes diminuiu. No Norte foram 29.220, 89.485 no Nordeste, 378.564 no Sudeste, 156.853 no Sul e 47.374 no Centro-Oeste. Já o número de óbitos aumentou em todas as regiões, sendo 170 no Norte, 446 no Nordeste, 1.288 no Sudeste, 497 no Sul e 311 no Centro-Oeste. ${ }^{(58)}$

\section{A visibilidade social do adoecimento ocupacional e dos acidentes do trabalho}

Sabemos que vivemos em uma sociedade capitalista e é intrínseca ao modo capitalista de produção a existência de lucro. Saliente-se que nesse momento, em especial, assistimos ao crescimento econômico do nosso país. O Brasil alcançou a oitava posição no "ranking" dos países mais ricos do mundo. De acordo com os dados do Fundo Monetário Internacional (FMI), o Produto Interno Bruto (PIB) do Brasil alcançou US\$ 1,91 trilhão, em 2010. No topo da lista dos maiores PIBs do mundo estão Estados Unidos (US\$ 14,79 trilhões), China (US\$ 5,36 trilhões) e Japão (US\$ 5,27 trilhões). Imediatamente à frente do Brasil, em sétimo lugar, está a Itália (US\$ 2,12 trilhões). ${ }^{(59)}$

No entanto, as condições laborais e a observância às normas de segurança e medicina do trabalho não evoluíram no mesmo passo. Tanto é assim que uma das principais vitrines do governo federal, o Programa de Aceleração do

(58) BRASIL. Minitério da Previdência Social. Disponível em: <htttp://www.previdencia.gov.br>. Acesso em: 9 jun. 2011.

(59) JANGADEIRO ONLINE. Brasil deve se manter como $8^{\mathrm{a}}$ economia mundial no mandato do próximo presidente. Disponível em: <http://www.jangadeiroonline.com.br/tv/to-na-janga/brasil-devese-manter-como-8\%c2\%aa-economia-mundial-no-mandato-do-proximo-presidente/>. Acesso em: 2 jul. 2012. 
Crescimento (PAC), e o projeto "Minha Casa, Minha Vida" têm trabalhadores em condições degradantes. A partir de denúncias do Sindicato dos Trabalhadores da Construção Civil da região de Campinas, a reportagem da Folha de São Paulo visitou alojamentos e obras de casas populares do PAC e constatou:

(...) trabalhadores vivem em locais superlotados, sem ventilação e com problemas de higiene e saneamento.

Nos locais, podem ser vistos colchões ou beliches construídos com madeira da própria obra ao lado de botijões de gás e rede elétrica.

Os operários são contratados por empreiteiros terceirizados de grandes construtoras e ganham abaixo do piso da categoria (...). ${ }^{(60)}$

As condições precárias foram apontadas como o estopim para a deflagração das greves ocorridas no mês de março de 2011 em obras como a da hidrelétrica de Jirau (RO) e no complexo de Suape (PE). A preocupação que sobressai é a do cumprimento dos prazos; por isso, as empresas que comandam os projetos contratam dezenas de outras, verificando-se não somente a chamada terceirização, mas também a "quarteirização". Algumas empresas são criadas somente para que as que estão à frente do negócio não tenham que arcar com custos trabalhistas.

Por isso, o professor Marcus Orione, em artigo denominado "Crescimento brasileiro e operário em construção", denunciou:

(...) o PAC (Programa de Aceleração do Crescimento) vem sendo realizado com danos essenciais à classe trabalhadora (...)

Para mais fácil compreender tal fenômeno, façamos um destaque do que aconteceu na construção da hidrelétrica de Jirau e em outras obras abrangidas pelo PAC. (...)

Não são desconhecidas, por exemplo, as inadequadas terceirizações existentes no setor público, que se realizam, em geral, com prejuízos aos trabalhadores e, como corolário, ao interesse popular. A situação de Jirau só expôs a nervura da forma mais cruel possível.

São trabalhadores que vivem em condições desumanas em canteiros de obra, financiadas pelo poder público - naquele programa que o próprio governo chama de modelar (...). ${ }^{(61)}$

Acontecimentos como os da greve que explodiu de forma violenta na hidrelétrica de Jirau demonstram que mesmo as obras realizadas sob responsabilidade direta do poder público, no caso, o Poder Executivo Federal, não contaram com previsão de medidas preventivas e voltadas à proteção da saúde e segurança dos trabalhadores. Assim, mister é ressaltar que cumpre ao Governo,

(60) NAVARRO, Silvio. Minha Casa, Minha Vida tem trabalho degradante. Folha de São Paulo, São Paulo, 11 abr. 2011. Caderno A, p. 4.

(61) ORIONE, Marcus. Crescimento brasileiro e operário em construção. Folha de São Paulo, São Paulo, 10 mai. 2011. Caderno A, Coluna Tendências e Debates. p. 3. 
não somente quando desempenha papel de gestor de obra, mas em especial, como fiscalizador do cumprimento das normas vigentes, voltadas à segurança e medicina do trabalho, colocar como prioridade as condições de trabalho, para que seja executado de forma digna.

No Brasil, lamentavelmente, ainda estamos longe de colocar em prática o respeito à dignidade do trabalhador. Exemplo disso são os índices alarmantes de acidentes do trabalho que ainda ocorrem no país.

Por essa razão, no dia 3 de maio de 2011, o Tribunal Superior do Trabalho (TST) lançou um programa para prevenir acidentes de trabalho no país. Segundo o presidente desse Tribunal, João Oreste Dalazen, o programa de prevenção de acidentes será divulgado amplamente na mídia, com o objetivo de conscientizar a população sobre a gravidade do problema. ${ }^{(62)}$

Dados mais recentes da Previdência Social, já citados, mostram que em 2010 foram registrados 701.496 acidentes, com 2.712 mortes no último ano, uma média de mais de sete mortes por dia. As estatísticas não incluem dados do funcionalismo público e de trabalhadores informais. Os gastos do governo com auxílio doença, auxílio acidente e aposentadorias por invalidez chegam a $\mathrm{R} \$ 10,7$ bilhões por ano. ${ }^{(63)}$

Esse quadro alarmante evidencia que o adoecimento relacionado ao trabalho e os acidentes do trabalho, na realidade, não são problemas visíveis ou preocupantes na sociedade brasileira. Impõe-se questionar quais as razões dessa invisibilidade; mesmo diante de tanto dispêndio de dinheiro público, esse quadro trágico repete-se ao longo do tempo.

Pode-se afirmar que a invisibilidade do adoecimento relacionado ao trabalho tem como uma das causas a inexistência de uma efetiva política nacional de saúde do trabalhador. Os órgãos governamentais não trabalham de forma integrada; para ilustrar, mencione-se que a base de dados da Previdência Social, com as informações sobre o Fator Acidentário de Prevenção (FAP), bem como sobre o Nexo Técnico Epidemiológico Previdenciário (NTEP) deveria ser compartilhada com o SUS, e que isso não ocorre. Os Ministérios do Trabalho, da Previdência e da Saúde realizam esforços estanques, cada qual no seu segmento.

Destaque-se que a Vigilância Sanitária tem competência para atuar na área de saúde do trabalhador, conforme preveem a Lei Orgânica da Saúde, os Códigos de Saúde e o Sanitário do Estado de São Paulo, bem como a Constituição Estadual. No entanto, pode-se dizer que, por razões corporativistas, os auditores fiscais do trabalho resistem em efetivar a parceria com o órgão estadual.

(62) TRIBUNAL SUPERIOR DO TRABALHO. Programa Nacional de Prevenção de Acidentes de Trabalho. Disponível em: <http://www.tst.jus.br/web/trabalhoseguro/inicio>. Acesso em: 3 maio 2011. (63) JUSBRASIL. TST lança campanha contra acidentes de trabalho. Disponível em: <http://www. jusbrasil.com.br/noticias/2669750/tst-lanca-campanha-contra-acidentes-de-trabalho>. Acesso em: 11 jun. 2011. 
Além disso, a fiscalização é falha e não são destinados recursos suficientes para as medidas fiscalizatórias, voltadas à prevenção.

As causas para o elevado número de ocorrências dos acidentes e da eclosão de moléstias ocupacionais são as mais diversas, envolvendo falhas nos projetos dos sistemas de trabalho, dos equipamentos, das ferramentas, bem como deficiência nos processos de manutenção dos diversos elementos componentes do trabalho.

E ainda, saliente-se que as doenças e os acidentes do trabalho saem "barato" para o empregador, que prefere economizar, não investindo em programas de manutenção preventiva das máquinas e equipamentos (meios de produção). Cumpre ressaltar a importância da manutenção preventiva, que propicia a troca das peças e dos equipamentos antes que sua vida útil se acabe. Ilustre-se, aqui, que a ausência de equipamentos de proteção individual (EPIs) e fornecimento de EPls inadequados são fatores de ocorrência de acidentes do trabalho: assim, os trabalhadores da construção civil, por exemplo, caem de andaimes por falta de cinto de segurança ou guardacorpo; os trabalhadores da indústria sofrem acidentes mutiladores, pela inexistência de dispositivo de segurança na máquina que impeça a introdução do dedo na "boca de lesão" - zona de operação. A falta de treinamento também é um dos quesitos a ser considerado, quando há uma situação específica. É importante salientar que o direito de informação dos perigos e exposições a substâncias químicas é garantido legalmente.

Outro fator que contribui para o adoecimento e também para a ocorrência de acidentes são as longas jornadas de trabalho; a exigência de cumprimento de muitas horas extras é mais uma evidência da não visibilidade e da pouca importância que tem a saúde do trabalhador, que se transforma em uma peça da engrenagem do processo produtivo.

É preciso reverter esse quadro; o nosso país tem conquistado o desenvolvimento econômico, encontrando-se entre as nações mais ricas do mundo. Urge seja alcançado também o desenvolvimento social, para que efetivamente o Brasil possa tornar-se uma sociedade desenvolvida. Para tanto, é necessário que, ao mesmo tempo em que se eleva o consumo de bens e serviços, não sejam esquecidas as condições de trabalho daqueles que produzem tais bens.

Pois, como diz Sebastião Geraldo de Oliveira, "a dignificação do trabalho inverte a ordem de apreciação, colocando o homem como valor primeiro, em função do qual está estruturada a ordem econômica e social."(64) Para o alcance desse objetivo todos devem estar envolvidos, o governo e a sociedade como um todo.

(64) OLIVEIRA. op. cit. 


\section{CONSIDERAÇÕES FINAIS}

A área da saúde do trabalhador pertence ao campo da Saúde Pública e envolve, obrigatoriamente, atuação de outras áreas do conhecimento, como os da engenharia, psicologia, sociologia, dentre outras, tanto quanto o direito. Incumbe a todos, e, particularmente, aos operadores do direito do trabalho, efetuar maior reflexão a respeito da efetividade da proteção jurídica à saúde dos trabalhadores.

Vivemos em uma sociedade de consumo, cada vez mais estimulado, onde o que importa é adquirir o último lançamento tecnológico, que logo estará obsoleto, para que outro seja comprado e descartado. Ignora-se o meio ambiente, e em especial o meio ambiente de trabalho e a dignidade da pessoa que produz os bens e serviços.

É preciso que a academia, as empresas, o poder público, enfim, todos se esforcem para destacar que o essencial é a dignidade humana, como princípio norteador de toda atividade econômica, conforme artigo 170 da Constituição Federal e um dos fundamentos da República Federativa do Brasil.

\section{REFERÊNCIAS}

ANTUNES, Ricardo. Adeus ao trabalho? Ensaio sobre as metamorfoses e a centralidade do mundo do trabalho. São Paulo: Cortez, 2010.

ASSUNÇÃO, Ada Ávila; VILELA, Lailah Vasconcelos Oliveira. Lesões por esforços repetitivos: guia para profissionais de saúde. Piracicaba: Cerest, 2009. p. 14.

BALLONE, G. J. Síndrome de Burnout. In: PsiqWeb. Revisto em 2009. Disponível em: <www.psiqweb.med.br>. Acesso em: 12 jul. 2012.

BAPTISTA, Renata Coelho. Doenças e outros agravos à saúde produzidos pelo trabalho. Cadernos Interdisciplinares: Saúde, Tecnologia e Questão Social. v. 1, n. 1, 2004. Disponível em: <www.higieneocupacional.com.br/ download/doenças-agravos.baptista.pdf>. Acesso em: 12 jul. 2012.

BENJAMIN, Walter. Sobre o conceito de história. In: BENJAMIN, Walter. Obras escolhidas. São Paulo: Brasiliense, 2008.

BRASIL. Ministério da Saúde. Dor relacionada ao trabalho: lesões por esforços repetitivos (LER), distúrbios osteomusculares relacionados ao trabalho (Dort). Brasília, 2012. Disponível em: <http://bvsms.saude.gov.br/bvs/ publicacoes/dor_relacionada_trabalho_ler_dort.pdf>. Acesso em: 29 maio 2012. 
Ministério da Saúde. Portal da Saúde. Centro de Referência em

Saúde do Trabalhador. Disponível em: <http://portal.saude.gov.br/portal/ saude/visualizar_texto.cfm?idtxt=30427\&janela $=1$ www.saude.gov.br $>$. Acesso em: 21 dez. 2011.

Ministério da Saúde. Portal da Saúde. Portaria amplia número de Centros de Saúde do Trabalhador. Disponível em: <http://portalsaude.saude. gov.br/portalsaude/noticia/3771/162/portaria-amplia-numerode-centros-desaude-do-trabalhador.html>. Acesso em: 21 dez. 2011.

. Ministério da Saúde. Portal da Saúde. Rede Nacional de Atenção à Saúde do Trabalhador. Disponível em: <http://portal.saude.gov.br/portal/ saude/visualizar_texto.cfm?idtxt=25085\&janela $=1$ www.saude.gov.br>. Acesso em: 21 dez. 2011.

COMPARATO, Fábio Konder. A afirmação histórica dos direitos humanos. São Paulo: Saraiva, 2003.

CUNHA NETO, Hugo Leonardo da; FIGUEIREDO, Rúbia Thaís de; SOARES, Thayara Rejane Reis. OIT - Organização Internacional do Trabalho.

Disponível em: <http://www.ebah.com.br/content/ABAAAA3ikAB/oit>. Acesso em: 13 maio 2011.

DEJOURS, Christophe. A loucura do trabalho. São Paulo: Cortez-Oboré, 1988.

GORZ, André. Crítica da divisão do trabalho. São Paulo: Martins Fontes, 2001.

HOBSBAWN, Eric J. Mundos do trabalho. São Paulo: Paz e Terra, 2000.

HUBERMAN, Leo. História da riqueza do homem. Rio de Janeiro: Guanabara, 1986.

JANGADEIRO ONLINE. Brasil deve se manter como $8^{a}$ economia mundial no mandato do próximo presidente. Disponível em: <http://www.jangadeiroonline. com.br/tv/to-na-janga/brasil-deve-se-manter-como-8\%c2\%aa-economiamundial-no-mandato-do-proximo-presidente/>. Acesso em: 2 jul. 2012.

JUSBRASIL. TST lança campanha contra acidentes de trabalho. Disponível em: <http://www.jusbrasil.com.br/noticias/2669750/tst-lanca-campanhacontra-acidentes-de-trabalho>. Acesso em: 11 jun. 2011.

LOURENÇO, Edvânia Ângela de Souza; BERTANI, Íris Fenner. Invisibilidade social das doenças relacionadas ao trabalho: desafios para a reabilitação profissional. In: SEMINÁRIO DE SAÚDE DO TRABALHADOR DE FRANCA, 2010, Franca, SP. Proceedings... Disponível em: <http://www.proceedings. scielo.br/scielo.php?script=sci_arttext\&pid=MSC0000000112010000100020\& ng=en\&nrm=iso? >. Acesso em: 2 jul. 2012. 
MAENO, Maria; CARMO, José Carlos do. Saúde do trabalhador no SUS: aprender com o passado, trabalhar o presente, construir o futuro. São Paulo: Hucitec, 2005.

MELO, Raimundo Simão de. Direito ambiental do trabalho e a saúde do trabalhador. São Paulo: LTr, 2008.

MENDES, René; DIAS, Elizabeth Costa. Da medicina do trabalho à saúde do trabalhador. Revista de Saúde Pública, São Paulo, v. 25, n. 5, p. 341-9, 1991.

NAVARRO, Silvio. Minha Casa, Minha Vida tem trabalho degradante. Folha de São Paulo, São Paulo, 11 abr. 2011. Caderno A, p. 4.

NOGUEIRA, Diogo Pupo. Introdução à segurança, higiene e medicina do trabalho. In: Curso de medicina do trabalho. São Paulo: Fundacentro,1979. v. 1.

OLIVEIRA, Sebastião Geraldo de. Proteção jurídica à saúde do trabalhador. São Paulo: LTr, 2010.

ORGANIZAÇÃO INTERNACIONAL DO TRABALHO. Oficina Internacional del Trabajo. Oficina del Director General. Mensaje de Juan Somavia, Director General de la Oficina Internacional del Trabajo, con ocasión del Día Mundial de la Seguridad y Salud en el Trabajo. Disponível em: <http://www.ilo.org/public/ spanish/bureau/dgo/speeches/somavia/2011/osh.pdf>. Acesso em: 9 jun. 2011.

ORGANIZAÇÃO PAN-AMERICANA DA SAÚDE. Declaração de Alma-Ata. Alma-Ata, 1978. Disponível em: <http://www.opas.org.br/coletiva/uploadArq/ Alma-Ata.pdf>. Acesso em: 2 jul. 2012.

ORGANIZACIÓN INTERNACIONAL DEL TRABAJO. Las actividades de la OIT en el Mundo después de 1945 (Parte 2: 1960-1988). Disponível em: <http://www.ilo.org/public/spanish/support/lib/century/content/1977.htm>. Acesso em: 13 maio 2011.

ORIONE, Marcus. Crescimento brasileiro e operário em construção. Folha de São Paulo, São Paulo, 10 mai. 2011. Caderno A, Coluna Tendências e Debates. p. 3.

PADILHA, Norma Sueli. Do meio ambiente do trabalho equilibrado. São Paulo: LTr, 2002.

RAMALHO, Carolina Calmon et al. Viver na baia: dimensões psicossociais da saúde e do controle no trabalho de teleatendimento. Cadernos de Psicologia Social e do Trabalho, São Paulo, v. 11, n. 1, p. 19-39, 2008.

SILVA, Nadia T. Demoliner Lacerda da. Negociação coletiva e o meio ambiente do trabalho. In: SANTOS, Enoque Ribeiro do; SILVA, Otavio Pinto e (Coord.). Temas controvertidos do direito coletivo do trabalho no cenário nacional e internacional. São Paulo: LTr, 2006. p. 245-254. 
SILVA, Otavio Pinto e. Subordinação, autonomia e parassubordinação nas relações de trabalho. São Paulo: LTr, 2004.

SÜSSEKIND, Arnaldo. Convenções da OIT. São Paulo: LTr, 1998.

TEIXEIRA, Sueli. A depressão no meio ambiente do trabalho e sua

caracterização como doença do trabalho. Revista LTr, São Paulo, v. 73, n. 5, 527-536, 2009.

TRIBUNAL SUPERIOR DO TRABALHO. Programa Nacional de Prevenção de Acidentes de Trabalho. Disponível em: <http://www.tst.jus.br/web/ trabalhoseguro/inicio>. Acesso em: 3 maio 2011.

VENCO, Selma. Centrais de atendimento: a fábrica do século XIX nos serviços do século XXI. Revista de Saúde Ocupacional, São Paulo, v. 31, n. 114, p. 7-18, 2006. 